\title{
Genetic variation within and among the wild populations of Alhagi graecorum using ISSR markers
}

\author{
Ghada M. Abd El- hak¹, Shafik D. Ibrahim², Atif Halem¹, Hussam Zaki Hassan¹, \\ Walaa A. Rayan ${ }^{*}$
}

${ }^{1}$ Botany Department, Faculty of Science, Ain Shams University, Cairo, Egypt.

${ }^{2}$ Agricultural Genetic Engineering Research Institute (AGERI), Agricultural Research Center, Giza, Egypt.

*Corresponding author: walaagenetics@yahoo.com

\begin{abstract}
:
Alhagi graecorum Boiss. (Camel thorn) (Family Fabaceae) is a wild plant which grows in salty soils and dry environment. It is native to Mediterranean and central Asia. Several studies have revealed the use of Alhagi plants in treating a wide spectrum of diseases. In this study, eight ISSR primers were used to assess genetic diversity of five populations of $A$. graecorum (El-Dakhla Oasis; Botanical garden of botany department, Ain Shams University; Wadi El-Rayan; Qarun Lake and Siwa Oasis) using individual - and bulked samples-based approaches. Twenty five individuals were sampled, amplified separately and amplified as bulked DNA to identify polymorphism among the studied populations. In total, 101 and 97 bands were scored with $83.3 \%$ and $78.4 \%$ polymorphism, respectively. Average polymorphism information content (PIC) for amplified DNA of individual samples was 0.875 and bulked-samples was recorded 0.69 . Analysis of molecular variance (AMOVA) showed that $63 \%$ of the total variation was observed among populations while variation within populations accounted for the remaining $37 \%$. The highest genetic similarity index was $(0.99)$ among the studied Alhagi genotypes was recorded between the two genotypes 6 and 7 both individuals were belonging to Ain Shams University population, while among inter populations was $(0.853 \%)$ between Qarun Lake and Siwa Oasis populations. The UPGMA cluster analysis divided the 25 individuals and bulked samples into two main groups. Each group was further subdivided into many sub-clusters, PCoA was also carried out and in agreement with the UPGMA. The obtained results demonstrate that the ISSR markers were efficient for evaluation of the genetic relationships between intra- and inter-population due to their efficiency in revealing polymorphism.
\end{abstract}

Key words: Medicinal plant, Alhagi graecorum, Genetic diversity, Molecular markers, ISSR.

\section{INTRODUCTION}

The Alhagi genus (commonly known as Camel thorn, Caspian manna or Persian manna) belongs to family Fabaceae and has been placed under sub-family Papilionaceae (Ali, 1977), commonly occur in dry lands associated with low rainfall, high salinity and alkalinity in waste places (Kawase and Kanno, 1983). Alhagi genus comprises different species such as $A$. pseudalhagi M. Mieb. Desv., A. graecorum Boiss., A. sparsifolia Shap., A. maurorum Medik. (Badshah and Hussain, 2011). Alhagi graecorum Boiss is a wild plant which grows in Nile and canal banks, roadside and lake borders. It is distributed all over the world as in North Africa, South East Europe, East Mediterranean and Western Asia (Boulos, 1966). Boulos (1999) mentioned that, A. graecorum has long been treated as A. maurorum Medik. in Egypt (Täckholm, 1974). On the other hand, Meikle (1977) distinguishes 2 species in Cyprus: A. graecorum and $A$. maurorum, the latter species being represented by two varieties.

The rate of seed germination is very low (Hassanein and Mazen, 2001), although various species of Alhagi propagates 


\section{Genetic variation within and among the wild populations}

conventionally through seeds. Therefore, an efficient large scale propagation of this rare plant species is an essential prerequisite for meeting the upcoming pharmaceutical requirements, as well as for its sustainable utilization (Agarwal et al., 2015).

Analysis of genetic diversity and relatedness between or within different species, populations and individuals is a prerequisite towards effective utilization and protection of plant genetic resources (Weising et al., 1995). It is generally recognized that plant genetic diversity changes in time and space. The extent and distribution of genetic diversity in a plant species depends on its evolution and breeding system, ecological and geographical factors, past bottlenecks, and often by many human factors (Rao and Hodgkin, 2002). One of the most important decisions to be used is DNA fingerprinting technique. Molecular markers have proven to be valuable tools in the evaluation of genetic variation both within and between species (Powell et al., 1996). Molecular biology has contributed to the development of DNA- based markers that can be used for genotype identification, fingerprinting, genetic mapping and diversity assessment (Khazaei et al., 2016). On the other hand, ISSRs are DNA-based markers permit detection of polymorphisms in inter-microsatellite loci (Karaca and Izbirak, 2008). These markers cover a large portion of the genome; ISSR may reveal a high number of polymorphic fragments per primer (Meyer et al., 1993). Moreover, ISSRs have high reproducibility possibly due to the using of single longer primers (16-25 mers) that can be di-, tri-, tetra- or penta-nucleotide as compared to RAPD primers (10- mers) which permits the subsequent use of high annealing temperature (45-60 ${ }^{\circ} \mathrm{C}$ ) leading to higher stringency (Tikunov et al., 2003; Rakoczy- Trojanowska and Bolibok, 2004). ISSRs segregate mostly as dominant markers following simple Mendelian inheritance. However, they have also been shown to segregate as co-dominant markers in some cases thus enabling distinction between homozygotes and heterozygotes (Akagi et al., 1996; Ratnaparkhe et al., 1998; Wang et al., 1998; Sankar and Moore, 2001). ISSR technique possesses a number of limitations. For instance, there is the possibility that fragments with the same mobility originate from non-homologous regions, which can contribute to some distortion in the estimates of genetic similarities. The molecular nature of the polymorphism can be known only if the fragments extracted from the gel are sequenced (Reddy et al., 2002).

ISSR molecular markers are widely used for population genetic analysis of different plants generating more reliable and reproducible bands than RAPD (Nagaoka and Ogihara, 1997; Zhang and Dai, 2010). It is used efficiently for studying genetic diversity of plants (Ma et al., 2008; Etminan et al., 2016). Many investigators studied the genetic diversity and polymorphism using ISSR molecular primers on different plant species as Salvadora persica (Monfared et al., 2018), Lotus species (Ducar et al., 2018), Phaseolus vulgaris (Cabral et al., 2018), Teucrium polium (Tapeh et al., 2018), Pongamia plants (Aldoori et al., 2019), Capsicum species (Olatunji and Afolayan, 2019) and Stylosanthes scabra (Costa et al., 2019). Currently, there is no report on genomic DNA isolation and the use of ISSR markers for molecular identification and genetic diversity characterization of collected Alhagi graecorum from Egypt. Therefore, isolation, amplification, and characterization of genomic DNA of $25 \mathrm{~A}$. graecorum genotypes from different habitats in Egypt using eight ISSR molecular markers were carried out.

\section{MATERIALS AND METHODS}

Plant material: The material comprises 25 genotypes of Alhagi graecorum were collected from different five regions (five individuals from each region) were estimated. (1-5); El-Dakhla Oasis, (6-10); 
Botanical garden of botany department, Ain Shams University, (11-15); Wadi ElRayan, (16-20); Qarun Lake and (21-25); Siwa Oasis.

DNA extraction: Genomic DNA was extracted and purified from young leaves of the samples using 2\% CTAB extraction buffer according to (Doyle and Doyle, 1990). DNA concentrations of total genomic DNA in each sample were estimated using a spectrophotometer (TU 1880 Double Beam UV-VIS). All the DNA samples were stored at $-20{ }^{\circ} \mathrm{C}$.

ISSR-PCR analysis: ISSR-PCR reactions were conducted using anchored primers, which were synthesized by Eurofins, Germany. Their names and sequences are indicated in Table (1). Amplification was performed in a Gene Amp ${ }^{\circledR}$ PCR System 9700 thermal cycler (Applied Biosystems) programmed using the temperature conditions as shown in Table (2). Electrophoresis of DNA samples were performed on $1.7 \%$ agarose gel and visualized with $0.5 \mathrm{mg} / \mathrm{ml}$ ethidium bromide. DNA bands were photographed under UV light. The size of each amplification product was automatically estimated using UV soft image analyzer system.

\section{Bulking DNA}

Aliquots $(10 \mu \mathrm{l})$ of the same individuals DNA concentration were mixed into a bulk of DNA representing each region. Hence, the outcome was 5 bulked DNA samples representing the different populations of $A$. graecorum included in this study. Eight ISSR primers were used to amplify the bulked DNA samples with the same conditions.

\section{Statistical analysis}

The analysis of molecular variance (AMOVA): This analysis was performed to estimate the variance components and their significance levels of genetic variation within and among populations using GenALEx program.

Genetic relatedness and cluster analysis: The scored binary data generated by ISSR marker was compared to determine the genetic relatedness of the $25 \mathrm{~A}$. graecorum genotypes. Similarity matrices and cluster analyses for ISSR markers were performed individually as well as collectively. The ISSR binary matrices were processed using the Bio-Rad diversity database software package and converted into similarity matrices according to Dice coefficient (Dice, 1945; Sneath and Sokal, 1973). The formula used by Dice to estimate the genetic similarity coefficient (GS) between two genotypes was as follows:

$$
\text { Dice formula: } G S i j=2 a /(2 a+b+c)
$$

Where GSij is the measure of genetic similarity between individuals $i$ and $j$, (a) is the number of bands shared by $i$ and $j$, (b) is the number of bands present in $i$ and absent in $\mathrm{j}$, and (c) is the number of bands present in $\mathrm{j}$ and absent in $\mathrm{i}$.

Determining true genetic dissimilarity between individuals is an important and decisive point for clustering and analyzing diversity within and among populations (Kosman and Leonard, 2005). The UPGMA (Unweighted Pair -Group Method with Arithmetic Mean) is the algorithmic

Table 1: The list of primers and their nucleotide sequences used for ISSR markers in amplification of A. graecorum DNA.

\begin{tabular}{ccl} 
No. & Primer code & Primer nucleotide sequence $\left(\mathbf{5}^{\prime} \rightarrow \mathbf{3}^{\prime}\right)$ \\
\hline 1 & ISSR-1 & 5'-AGAGAGAGAGAGAGAGYC-3' \\
2 & ISSR-4 & 5'-ACACACACACACACACYG-3' \\
3 & ISSR-5 & 5'-GTGTGTGTGTGTGTGTYG-3' \\
4 & ISSR-6 & 5'-CGCGATAGATAGATAGATA-3' \\
5 & ISSR-7 & 5'-GACGATAGATAGATAGATA-3' \\
6 & ISSR-9 & 5'-GATAGATAGATAGATAGC-3' \\
7 & ISSR-10 & 5'-GACAGACAGACAGACAAT-3' \\
8 & ISSR-18 & 5'-HVHCACACACACACACAT-3' \\
\hline
\end{tabular}

A: Adenine, T: Thymine, G: Guanine, C: Cytosine, H: (A or C or T) and V: (A or C or G). 


\section{Genetic variation within and among the wild populations}

Table 2: The ISSR-PCR reaction parameters.

\begin{tabular}{llll}
\hline Steps & Temperature & Time & Cycles \\
\hline Initial denaturation & $94^{\circ} \mathrm{C}$ & $7 \mathrm{~min}$ & 1 \\
Denaturation & $94^{\circ} \mathrm{C}$ & $1 \mathrm{~min}$ & \\
Annealing & $40-50^{\circ} \mathrm{C}$ & $1 \mathrm{~min}$ & 40 \\
Extension & $72^{\circ} \mathrm{C}$ & $2 \mathrm{~min}$ & \\
Final extension & $72^{\circ} \mathrm{C}$ & $7 \mathrm{~min}$ & 1 \\
\hline
\end{tabular}

method used in this study, which uses a specific series of calculations to estimate a tree (Sokal and Michener, 1958).

Principal coordinates analysis (PCoA): Also known as classical multidimensional scaling which is a set of data analyses that show the structure of complex distance-like data represented in a high dimensional space into the lowest possible dimensional space. Prinicipal coordinates analysis (PCoA) resembles principal component analysis (PCA) but it takes dissimilarity as input (Pavoine et al., 2004; Gower, 2015). PCoA was performed based on the matrix calculated for each marker using PAST software (Hammer et al., 2001).

\section{RESULTS AND DISCUSSION}

\section{Characterization of the capability of each ISSR primer to detect polymorphism}

The percentage of polymorphism detected by the eight ISSR primers among Alhagi samples was shown in Table (3) and Figure (1). El-Dakhla Oasis exhibited the highest value of polymorphism $60 \%$ for ISSR-5, while $87.5 \%$ among Ain Shams University population with ISSR-9 as compared to the other primers. The selected primers, ISSR- 5 and ISSR- 9 produced the highest value of polymorphism $90 \%$ and 85.7\%, respectively among Wadi El-Rayan population; also in Qarun Lake the same primers produced the highest value of polymorphism $100 \%$ and $77.78 \%$. High level of genetic variation was observed using ISSR-5 and ISSR-10 primers among
Siwa Oasis population with $71.43 \%$ and 69.23\% polymorphism, respectively (Table 3). Inter simple sequence repeat markers involves PCR amplification of DNA using a single primer composed of microsatellite sequences, sometimes anchored at the 3 `or 5 end by 1 to 4 nucleotides. These primers target the simple sequence repeats and amplify the intervening region between the two SSRs in opposite orientations (González et al., 2002). Reddy et al. (2002) reported that the extent of polymorphism varies with the nature (unanchored, $3{ }^{`}$-anchored, or $5{ }^{`}$-anchored) and sequence of the repeats (motif) in the primer employed. Generally when 5` anchored primers are used, the amplified products include the microsatellite sequences and their length variations across a genome and therefore give more number of bands and a higher degree of polymorphism. Usually di-nucleotide repeats, anchored either at $3{ }^{`}$ or 5 ' end reveal high polymorphism (Blair et al., 1999; Joshi et al., 2000; Nagaoka and Ogihara, 1997). The primers anchored at 3 end give clearer banding pattern as compared to those anchored at $5^{`}$ end (Tsumura et al., 1996; Blair et al.,1999).

The present results showed that most of the primers revealed high polymorphism contained di- nucleotide repeats; GA, CA, $A C$ and $A G$ indicating abundance of these repeats in $A$. graecorum genome. These results are in accordance with results obtained by Rawat et al. (2018) who reported that di- nucleotide primers with repeats; GA, CT, CA, GT, AC, AG and TC 
Ghada M. Abd El- hak et. al

Table 3: The percentage of polymorphism recorded using eight ISSR primers in $A$. graecorum genotypes collected from five different locations.

\begin{tabular}{|c|c|c|c|c|c|}
\hline $\begin{array}{l}\text { Primer } \\
\text { code }\end{array}$ & Location & $\begin{array}{l}\text { Total no. of } \\
\text { bands }\end{array}$ & $\begin{array}{l}\text { Monomorphic } \\
\text { bands }\end{array}$ & $\begin{array}{l}\text { Polymorphic } \\
\text { bands }\end{array}$ & $\begin{array}{l}\text { Percentage of } \\
\text { polymorphism }\end{array}$ \\
\hline \multirow{5}{*}{ ISSR-1 } & El-Dakhla oasis & 3 & 3 & 0 & 00.00 \\
\hline & Ain shams university & 11 & 9 & 2 & 18.18 \\
\hline & Wadi El-Rayan & 7 & 3 & 4 & 57.14 \\
\hline & Qarun lake & 10 & 3 & 7 & 70.00 \\
\hline & Siwa oasis & 11 & 10 & 1 & 9.10 \\
\hline \multirow{5}{*}{ ISSR-4 } & El-Dakhla oasis & 4 & 4 & 0 & 00.00 \\
\hline & Ain shams university & 9 & 7 & 2 & 22.22 \\
\hline & Wadi El-Rayan & 11 & 7 & 4 & 36.36 \\
\hline & Qarun lake & 10 & 6 & 4 & 40.00 \\
\hline & Siwa oasis & 8 & 6 & 2 & 25.00 \\
\hline \multirow{5}{*}{ ISSR-5 } & El-Dakhla oasis & 5 & 2 & 3 & 60.00 \\
\hline & Ain shams university & 10 & 10 & 0 & 00.00 \\
\hline & Wadi El-Rayan & 10 & 1 & 9 & 90.00 \\
\hline & Qarun lake & 12 & 0 & 12 & 100.00 \\
\hline & Siwa oasis & 7 & 2 & 5 & 71.43 \\
\hline \multirow{5}{*}{ ISSR-6 } & El-Dakhla oasis & 1 & 1 & 0 & 00.00 \\
\hline & Ain shams university & 9 & 8 & 1 & 11.11 \\
\hline & Wadi El-Rayan & 8 & 5 & 3 & 37.50 \\
\hline & Qarun lake & 9 & 6 & 3 & 33.33 \\
\hline & Siwa oasis & 11 & 7 & 4 & 36.36 \\
\hline \multirow{5}{*}{ ISSR-7 } & El-Dakhla oasis & 7 & 5 & 2 & 28.57 \\
\hline & Ain shams university & 7 & 5 & 2 & 28.57 \\
\hline & Wadi El-Rayan & 4 & 4 & 0 & 00.00 \\
\hline & Qarun lake & 7 & 6 & 1 & 14.29 \\
\hline & Siwa oasis & 7 & 6 & 1 & 14.29 \\
\hline \multirow{5}{*}{ ISSR-9 } & El-Dakhla oasis & 6 & 3 & 3 & 50.00 \\
\hline & Ain shams university & 8 & 1 & 7 & 87.50 \\
\hline & Wadi El-Rayan & 7 & 1 & 6 & 85.71 \\
\hline & Qarun lake & 9 & 2 & 7 & 77.78 \\
\hline & Siwa oasis & 9 & 4 & 5 & 55.56 \\
\hline \multirow{5}{*}{ ISSR-10 } & El-Dakhla oasis & 10 & 7 & 3 & 30.00 \\
\hline & Ain shams university & 11 & 10 & 1 & 9.10 \\
\hline & Wadi El-Rayan & 11 & 6 & 5 & 45.45 \\
\hline & Qarun lake & 13 & 5 & 8 & 61.54 \\
\hline & Siwa oasis & 13 & 4 & 9 & 69.23 \\
\hline \multirow{5}{*}{ ISSR-18 } & El-Dakhla oasis & 8 & 5 & 3 & 37.50 \\
\hline & Ain shams university & 8 & 8 & 0 & 00.00 \\
\hline & Wadi El-Rayan & 8 & 6 & 2 & 25.00 \\
\hline & Qarun lake & 8 & 4 & 4 & 50.00 \\
\hline & Siwa oasis & 8 & 4 & 4 & 50.00 \\
\hline
\end{tabular}


Genetic variation within and among the wild populations
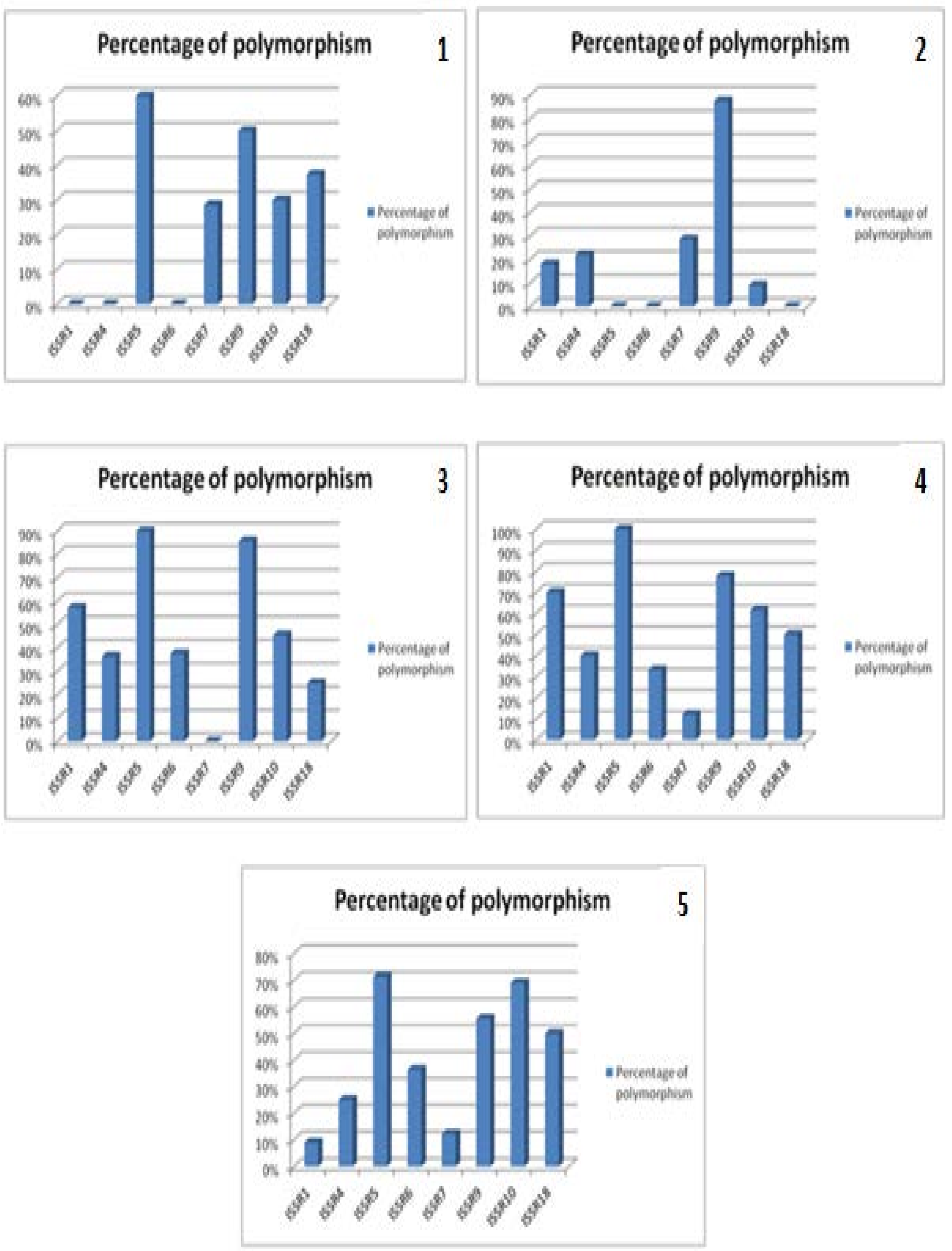

Figure 1: Polymorphism values detected using eight ISSR primers for Alhagi samples gathered from 1. El-Dakhla Oasis; 2. Ain Shams University; 3. Wadi El-Rayan; 4. Qarun Lake and 5. Siwa Oasis. 
are abundant in the Melia dubia genome. This finding is reinforced by Bhagyawant and Srivastava (2008) who showed that in chick pea, dinucleotide repeats amplified more bands than tri-nucleotide and pentanucleotide ones. Rawat et al. (2018) also reported that the high polymorphism is attributed to the abundance of dinucleotide repeats in the studied genotypes. Similarly, abundance of di-nucleotide repeats has been reported in other species like Curculigo latifolia, (Ranjbarfard et al., 2014). Also, abundance of tri-nucleotide repeats in Azadirachta indica (Ranade and Farooqui, 2002) and tri and tetra repeat in Tectona grandis (Ansari et al., 2012) has been reported. It was observed that AG and GA based primers were given high polymorphism (Joshi et al., 2000; Reddy et al., 2002; Shilpa and Krishnan, 2016). The differences between studies probably depend on the primer used and the band location (Ismail et al., 2019).

\section{Genetic diversity revealed by individuals- and bulked-samples-based approaches using ISSR markers in $A$. graecorum}

Genetic relatedness/diversity between the 25 A. graecorum genotypes was analyzed using ISSR markers. Polymorphism revealed by eight ISSR primers was shown in Table (4) and Figure 2. Generally, a total of 101 bands were amplified among the 25 individuals; including 16 monomorphic DNA fragments and 85 were polymorphic with percentage $83.3 \%$, three of them are unique bands. Whereas the number of polymorphic amplicons varied from 7 to 15 for ISSR-18 and ISSR-1, respectively (Table 4). The polymorphic information content (PIC) varied from 0.778 to 0.948 values where primer ISSR-7 had the lowest PIC value while primer ISSR-1 had the highest value with average 0.875 . On the other hand, The ISSR fingerprinting patterns revealed by the eight primers used among the five bulked DNA samples of Alhagi populations are showed in Figure (3). The genetic polymorphism obtained by the eight ISSR primers between the five Alhagi populations, which yielded total number of 97 bands; 76 of these were polymorphic (78.4\%) throughout the five populations with 18 unique bands (Table 5). The number of polymorphic bands varied from 3 to 16 with ISSR-18 and ISSR-10, respectively but the percentage of the polymorphism are varied between $42.8 \%$ and $100 \%$ with ISSR-18 and ISSR-9, respectively. Polymorphic information content (PIC) varied among different ISSR primers from 0.268 to 0.768 with average 0.69. Analysis of molecular variance (AMOVA), used to estimate the genetic variability among populations, revealed significant genetic variance between and within the studied populations (Table 6), being most of the genetic diversity found among the populations (63\%). ISSR markers can be used in population genetic studies of plant species as they effectively detect very low levels of genetic variation (Zietkiewicz et al., 1994). In the present study, ISSR markers were effective to characterize the relationship or genetic diversity between genotypes and among populations. They also may have potential for analysis biogeographic patterns among populations of a single plant species.

Geleta and Bryngelsson, (2009) studied the genetic variation on ten populations of Afroalpine giant lobelia, Lobelia rhynchopetalum, from results they found that, the percentage of polymorphic loci across all samples and within population was $78 \%$ and $27 \%$, respectively. The present results in agreement with Tanya et al. (2011) who genetically characterized 30 accessions of Jatropha curcas using ISSR markers and the analysis of molecular variance showed a high level of polymorphism (63\%) among populations and low polymorphism (37\%) within populations. Also, Mosula et al. (2014) studied the genetic diversity among three populations of Gentiana lutea using nine ISSR primers and according to the results of AMOVA, the high level of genetic 
Genetic variation within and among the wild populations
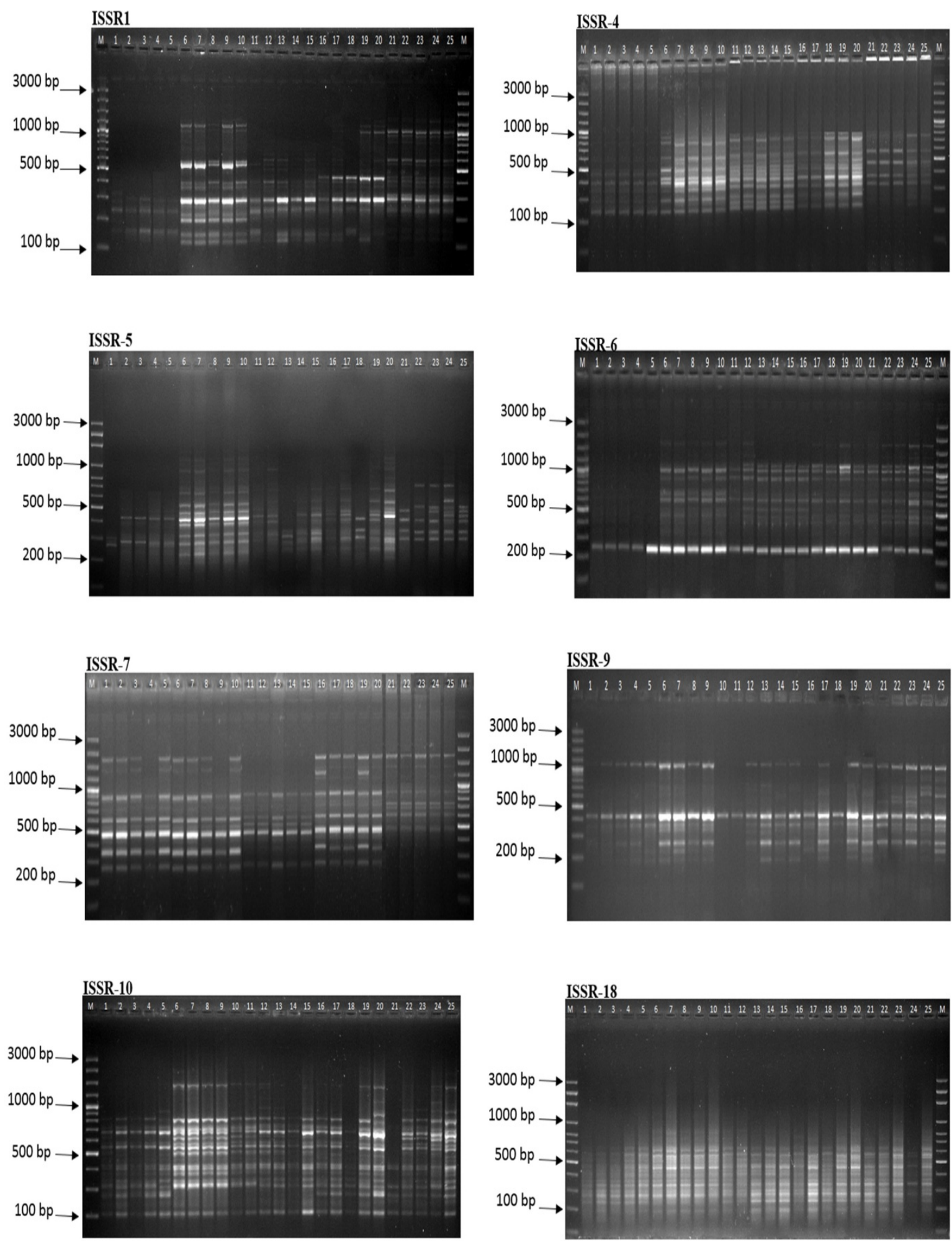

Figure 2: Agarose gel electrophoresis result for PCR amplicons using eight ISSR primers to genetically characterize DNA of $A$. graecorum genotypes (numbered from 125). $M$ refers to DNA marker 100 bp plus. (1-5); El-Dakhla Oasis, (6-10); Botanical garden of botany department, Ain Shams University, (11-15); Wadi El-Rayan, (16-20); Qarun Lake and (21-25); Siwa Oasis. 
Table 4: The total number of bands, polymorphic bands, monomorphic bands, percentage of polymorphism, unique bands, fragment size range and polymorphic information content (PIC) as revealed by ISSR analysis of $25 \mathrm{~A}$. graecorum genotypes.

\begin{tabular}{ccccccccc}
\hline S. & $\begin{array}{c}\text { Primer } \\
\text { name }\end{array}$ & $\begin{array}{c}\text { Total } \\
\text { no. of } \\
\text { bands }\end{array}$ & $\begin{array}{c}\text { Polymorphic } \\
\text { bands }\end{array}$ & $\begin{array}{c}\text { monomorphic } \\
\text { bands }\end{array}$ & $\begin{array}{c}\text { Percentage of } \\
\text { Polymorphism } \\
\text { (POL \%) }\end{array}$ & $\begin{array}{c}\text { Unique } \\
\text { bands }\end{array}$ & $\begin{array}{c}\text { Fragment } \\
\text { size range } \\
\text { (bp) }\end{array}$ & PIC \\
\hline $\mathbf{1}$ & ISSR-1 & 16 & 15 & 1 & 93.8 & - & $1397-120$ & 0.948 \\
$\mathbf{2}$ & ISSR-4 & 15 & 11 & 4 & 73 & 2 & $870-177$ & 0.868 \\
$\mathbf{3}$ & ISSR-5 & 15 & 15 & - & 100 & 1 & $1188-180$ & 0.9 \\
$\mathbf{4}$ & ISSR-6 & 11 & 10 & 1 & 90.9 & - & $1819-225$ & 0.849 \\
$\mathbf{5}$ & ISSR-7 & 10 & 7 & 3 & 70 & - & $1919-253$ & 0.778 \\
$\mathbf{6}$ & ISSR-9 & 9 & 8 & 1 & 88.9 & - & $1240-172$ & 0.92 \\
$\mathbf{7}$ & ISSR-10 & 15 & 12 & 3 & 80 & - & $1643-195$ & 0.92 \\
$\mathbf{8}$ & ISSR-18 & 10 & 7 & 3 & 70 & - & $976-184$ & 0.816 \\
& Total & $\mathbf{1 0 1}$ & 85 & 16 & - & $\mathbf{3}$ & - & - \\
& Average & 12.6 & 10.6 & 2 & $\mathbf{8 3 . 3}$ & & - & $\mathbf{0 . 8 7 5}$ \\
\hline
\end{tabular}

Table 5: Total number of bands, polymorphic bands, monomorphic bands, percentage of polymorphism, unique bands, fragment size range and polymorphic information content (PIC) as revealed by ISSR analysis of A. graecorum bulked DNA samples.

\begin{tabular}{ccccccccc}
\hline S. & $\begin{array}{c}\text { Primer } \\
\text { Name }\end{array}$ & $\begin{array}{c}\text { Total } \\
\text { no. of } \\
\text { bands }\end{array}$ & $\begin{array}{c}\text { Polymorphic } \\
\text { bands }\end{array}$ & $\begin{array}{c}\text { Monomorphic } \\
\text { bands }\end{array}$ & $\begin{array}{c}\text { Percentage of } \\
\text { polymorphism } \\
\text { (POL \%) }\end{array}$ & $\begin{array}{c}\text { Unique } \\
\text { bands }\end{array}$ & $\begin{array}{c}\text { Fragment } \\
\text { size range } \\
\text { (bp) }\end{array}$ & PIC \\
\hline $\mathbf{1}$ & ISSR-1 & 13 & 8 & 5 & 61.5 & 4 & $1277-130$ & 0.768 \\
$\mathbf{2}$ & ISSR-4 & 16 & 12 & 4 & 75 & 3 & $1216-198$ & 0.768 \\
$\mathbf{3}$ & ISSR-5 & 9 & 5 & 4 & 55.6 & - & $1442-162$ & 0.768 \\
$\mathbf{4}$ & ISSR-6 & 13 & 12 & 1 & 92.3 & 2 & $1600-345$ & 0.768 \\
$\mathbf{5}$ & ISSR-7 & 9 & 7 & 2 & 77.8 & 1 & $1780-320$ & 0.672 \\
$\mathbf{6}$ & ISSR-9 & 13 & 13 & - & 100 & 3 & $894-153$ & 0.768 \\
$\mathbf{7}$ & ISSR-10 & 17 & 16 & 1 & 94 & 5 & $1779-185$ & 0.768 \\
$\mathbf{8}$ & ISSR-18 & 7 & 3 & 4 & 42.8 & - & $849-176$ & 0.268 \\
& Total & $\mathbf{9 7}$ & 76 & 21 & & $\mathbf{1 8}$ & & \\
& Average & 12.1 & 9.5 & 2.6 & $\mathbf{7 8 . 4}$ & & & $\mathbf{0 . 6 9}$ \\
\hline
\end{tabular}




\section{Genetic variation within and among the wild populations}
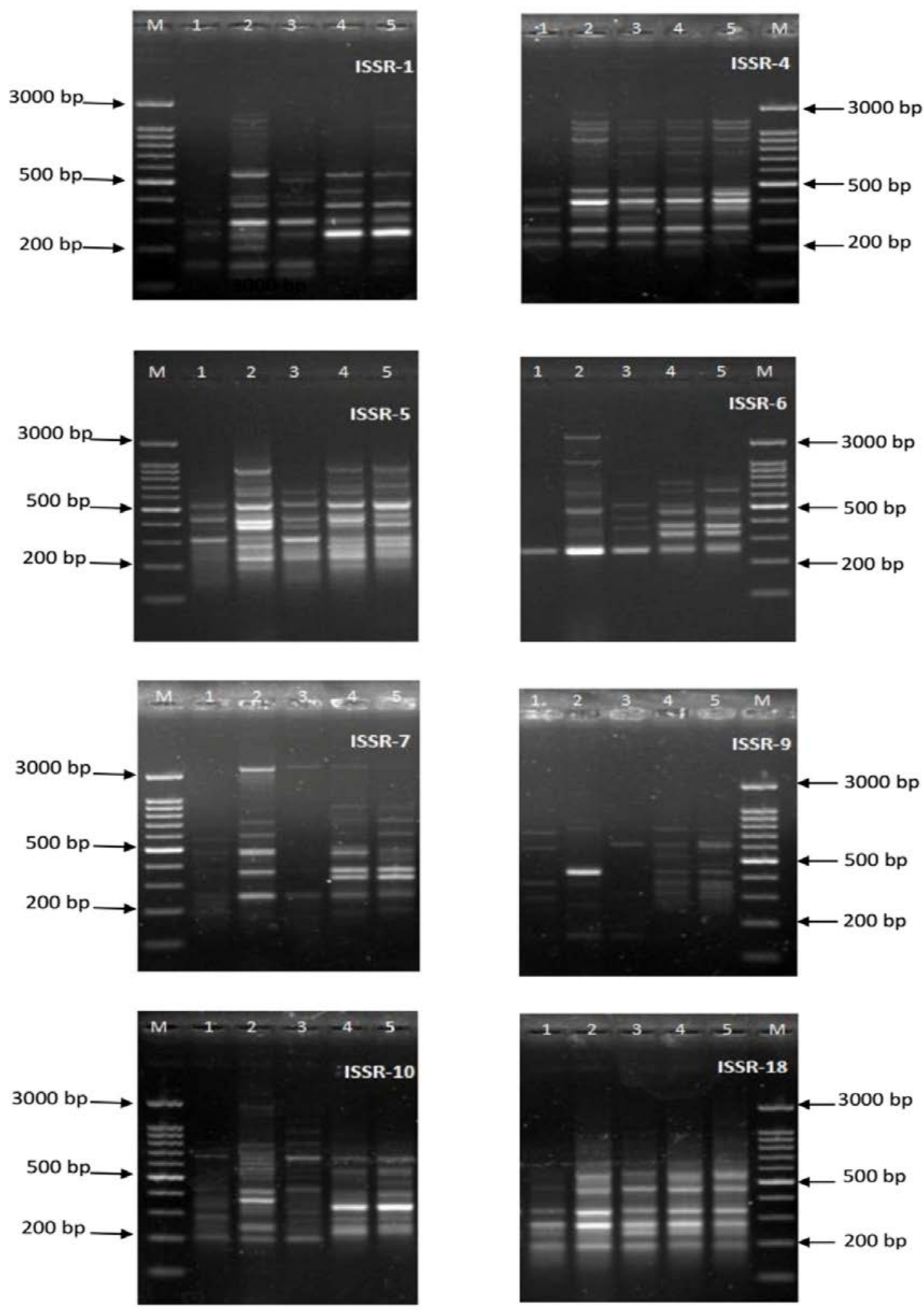

Figure 3: ISSR profiles (ISSRs 1, 4, 5, 6, 7, 9, 10 and 18) for $A$. graecorum bulked DNA samples. $M$ refers to DNA ladder (100 bp) plus. A. graecorum populations are 1. El-Dakhla Oasis; 2. Ain Shams University; 3. Wadi El-Rayan; 4. Qarun Lake and 5. Siwa Oasis. 
variation 59\% regard differences between populations and $41 \%$ within populations. Similarly, the molecular polymorphism was $67.18 \%$ with ten primers and withinpopulation variation was $32.34 \%$ of Pongamia pinnata using ISSR markers Sahoo et al. (2010). Costa et al. (2019) evaluated the genetic diversity of Stylosanthes scabra using ISSR molecular markers. They found from their results that ISSR primers revealed a total of 88 bands with $95 \%$ polymorphism at the species level. In addition, the AMOVA test revealed that $40 \%$ of the total genetic variation occurs within populations and $60 \%$ among populations.

In contrast, the molecular variance analysis (AMOVA) in four natural populations of Croton tetradenius using thirteen ISSR primers was found (87\%) within populations with a high level of polymorphism 94.8\% (Almeida-Pereira et al., 2017). Furthermore, many researches revealed that; the genetic variation within and among the populations of different plants by using ISSR markers and AMOVA analysis and concluded that this variation was higher within populations than among them as Murraya koenigii (Verma and Rana, 2011), Jatropha curcas (Arolu et al., 2012) and Ziziphus spina-christi (Alansi et al., 2016). Finally, genetic variation is a necessary condition for a species to adapt to environmental changes (Liu et al., 2015).

The using of ISSR primers is considered highly informative with the PIC value, this effectiveness of a marker depends on the information content and the number of markers produced individually (Thimmappaiah et al., 2009). If a PIC value is $>0.5$, then polymorphism is at a high level, while if it is between 0.25 and 0.5 , the polymorphism is normal (TurhanSerttas and Özcan, 2018). In the present work, the mean averages of PIC in the genotypes and bulked DNA samples (0.87 and 0.69), respectively. These high values similar to Gelotar et al. (2019), who recorded the value of average PIC was 0.85 among 19 genotypes of Amaranthus using 11 ISSR markers. Also, Monfared et al. (2018) who found the mean polymorphism information content (PIC) value was 0.63 among 50 genotypes of Salvadora persica . Recently, the genetic relationships of the varieties of Capsicum species using 10 ISSR primers were performed. Furthermore, the average polymorphism information content (PIC) was 0.67 (Olatunji and Afolayan, 2019). In other studies, the PIC values were mostly lower than our values; it is between 0.25 and 0.5 , such as (Moradkhani et al., 2015; Araujo et al., 2016 and Tapeh et al., 2018). The results of our study demonstrated that the ISSR method is sufficiently informative and powerful to estimate the genetic diversity in Alhagi populations.

\section{Genetic similarities matrix of $A$. graecorum as revealed by ISSR markers}

To investigate the genetic similarity among the 25 examined $A$. graecorum genotypes based on ISSR results, the scored data obtained from eight primers were analyzed using the Dice coefficient to compute the similarity matrix. This similarity matrix was used to generate a dendrogram using the UPGMA method. As shown in Table (7), the estimated similarities among the 25 Alhagi genotypes ranged from 0.49 to 0.99 . The highest genetic similarity (0.99) was between genotypes 6 and 7 (both individuals from Ain Shams University population), while the lowest genetic similarity $(0.49)$ was between genotypes 1 (individual from ElDakhla Oasis population) and 9 (individuals from Ain Shams University population).

On the other hand, the data resulted from ISSR scoring for the 5 bulked DNA $A$. graecorum populations were shown in Table (8). The estimated similarities ranged from 0.519 to 0.853 . The highest genetic similarity $(0.853 \%)$ was between Qarun Lake and Siwa Oasis populations, while the lowest genetic similarity $(0.519 \%)$ was between El-Dakhla Oasis and Ain Shams 


\section{Genetic variation within and among the wild populations}

Table 6: Analysis of molecular variance (AMOVA) for eight ISSR markers among $A$. graecorum populations.

\begin{tabular}{cccccc}
\hline $\begin{array}{c}\text { Source of } \\
\text { variations }\end{array}$ & $\begin{array}{c}\text { Degree of } \\
\text { freedom }\end{array}$ & $\begin{array}{c}\text { Sum of } \\
\text { squares }\end{array}$ & $\begin{array}{c}\text { Mean } \\
\text { square }\end{array}$ & $\begin{array}{c}\text { Variance } \\
\text { components }\end{array}$ & $\begin{array}{c}\text { \% of total } \\
\text { variance }\end{array}$ \\
\hline $\begin{array}{c}\text { Among } \\
\text { populations } \\
\text { Within } \\
\text { populations }\end{array}$ & 4 & 252.96 & 63.24 & 11.32 & $\mathbf{6 3}$ \\
\hline Total & 20 & 134.00 & 6.7 & 6.700 & 37 \\
\hline
\end{tabular}

Table 7: Genetic similarity matrix among the 25 A. graecorum genotypes as computed according to Dice's coefficient as revealed by ISSR markers.

\begin{tabular}{|c|c|c|c|c|c|c|c|c|c|c|c|c|c|c|c|c|c|c|c|c|c|c|c|c|c|}
\hline & 1 & 2 & 3 & 4 & 5 & 6 & 7 & 8 & 9 & 10 & 11 & 12 & 13 & 14 & 15 & 16 & 17 & 18 & 19 & 20 & 21 & 22 & 23 & 24 & 25 \\
\hline 1 & 1 & & & & & & & & & & & & & & & & & & & & & & & & \\
\hline 2 & 0.91 & 1 & & & & & & & & & & & & & & & & & & & & & & & \\
\hline 3 & 0.91 & 0.97 & 1 & & & & & & & & & & & & & & & & & & & & & & \\
\hline 4 & 0.83 & 0.92 & 0.92 & 1 & & & & & & & & & & & & & & & & & & & & & \\
\hline 5 & 0.86 & 0.92 & 0.89 & 0.92 & 1 & & & & & & & & & & & & & & & & & & & & \\
\hline 6 & 0.51 & 0.56 & 0.56 & \begin{tabular}{l|l|}
0.58 \\
\end{tabular} & 0.61 & 1 & & & & & & & & & & & & & & & & & & & \\
\hline 7 & 0.51 & 0.56 & 0.56 & 0.58 & 0.61 & \begin{tabular}{l|l}
0.99 \\
\end{tabular} & 1 & & & & & & & & & & & & & & & & & & \\
\hline 8 & 0.55 & 0.59 & 0.59 & 0.58 & 0.61 & 0.95 & 0.93 & 1 & & & & & & & & & & & & & & & & & \\
\hline 9 & 0.49 & 0.53 & 0.53 & 0.58 & \begin{tabular}{l|}
0.57 \\
\end{tabular} & 0.98 & 0.96 & 0.94 & 1 & & & & & & & & & & & & & & & & \\
\hline 10 & 0.51 & 0.56 & 0.54 & 0.53 & 0.58 & 0.94 & 0.93 & 0.95 & 0.93 & 1 & & & & & & & & & & & & & & & \\
\hline 11 & 0.58 & 0.62 & 0.59 & \begin{tabular}{l|l|}
0.63 \\
\end{tabular} & 0.64 & 0.68 & \begin{tabular}{l|l|l|}
0.68 \\
\end{tabular} & 0.71 & 0.70 & $\begin{array}{ll}0.73 \\
\end{array}$ & 1 & & & & & & & & & & & & & & \\
\hline 12 & 0.56 & 0.57 & 0.57 & 0.60 & 0.61 & 0.73 & 0.73 & 0.75 & 0.74 & $\begin{array}{ll}0.72 \\
\end{array}$ & $\begin{array}{ll}0.87 \\
\end{array}$ & 1 & & & & & & & & & & & & & \\
\hline 13 & 0.61 & 0.62 & 0.62 & 0.67 & 0.64 & 0.73 & 0.71 & 0.71 & 0.75 & 0.68 & 0.75 & 0.83 & 1 & & & & & & & & & & & & \\
\hline 14 & 0.66 & 0.64 & 0.67 & 0.70 & 0.64 & 0.67 & 0.65 & 0.67 & 0.68 & 0.64 & 0.75 & \begin{tabular}{l|l}
0.80 \\
\end{tabular} & 0.92 & 1 & & & & & & & & & & & \\
\hline 15 & 0.60 & 0.61 & 0.61 & 0.66 & 0.63 & 0.75 & 0.73 & 0.76 & 0.77 & 0.73 & 0.81 & 0.85 & 0.91 & 0.92 & 1 & & & & & & & & & & \\
\hline 16 & 0.66 & 0.62 & 0.62 & 0.63 & 0.63 & 0.63 & 0.63 & 0.64 & 0.61 & 0.64 & 0.71 & \begin{tabular}{l|l}
0.72 \\
\end{tabular} & \begin{tabular}{l|l}
0.69 \\
\end{tabular} & \begin{tabular}{l|l}
0.73 \\
\end{tabular} & 0.69 & 1 & & & & & & & & & \\
\hline 17 & 0.65 & 0.67 & 0.67 & 0.72 & 0.71 & 0.78 & 0.78 & 0.74 & 0.77 & $\begin{array}{ll}0.73 \\
\end{array}$ & 0.73 & 0.74 & 0.80 & 0.79 & 0.83 & 0.79 & 1 & & & & & & & & \\
\hline 18 & 0.68 & 0.69 & 0.69 & 0.67 & 0.66 & 0.62 & 0.62 & 0.64 & 0.61 & 0.64 & 0.71 & \begin{tabular}{l|l}
0.68 & \\
\end{tabular} & \begin{tabular}{l|l} 
\\
\end{tabular} & 0.75 & 0.71 & 0.80 & 0.81 & 1 & & & & & & & \\
\hline 19 & 0.62 & 0.63 & 0.63 & 0.67 & 0.68 & 0.77 & 0.77 & 0.73 & 0.76 & 0.74 & 0.69 & \begin{tabular}{l|l}
0.73 & \\
\end{tabular} & 0.74 & 0.76 & 0.79 & 0.76 & 0.90 & 0.78 & 1 & & & & & & \\
\hline 20 & 0.60 & 0.59 & \begin{tabular}{l|}
0.57 \\
\end{tabular} & 0.58 & 0.63 & 0.72 & 0.72 & 0.69 & 0.72 & 0.70 & 0.65 & \begin{tabular}{l|l}
0.72 & $C$ \\
\end{tabular} & 0.74 & 0.69 & 0.75 & 0.69 & 0.79 & 0.73 & 0.83 & 1 & & & & & \\
\hline 21 & 0.58 & 0.59 & 0.61 & 0.55 & 0.54 & 0.61 & 0.61 & 0.61 & 0.59 & 0.60 & 0.62 & 0.67 & 0.70 & 0.70 & 0.69 & 0.64 & 0.72 & 0.77 & 0.71 & 0.68 & 1 & & & & \\
\hline 22 & 0.58 & 0.59 & 0.61 & 0.60 & 0.61 & 0.69 & 0.69 & 0.66 & 0.69 & 0.63 & 0.65 & 0.74 & \begin{tabular}{l|l}
0.76 \\
\end{tabular} & 0.71 & 0.71 & 0.67 & 0.76 & 0.75 & 0.74 & 0.74 & 0.87 & 1 & & & \\
\hline 23 & 0.57 & 0.59 & 0.59 & 0.58 & 0.61 & 0.74 & 0.74 & 0.72 & 0.73 & 0.70 & 0.67 & 0.75 & \begin{tabular}{l|l} 
\\
\end{tabular} & 0.69 & 0.76 & 0.64 & 0.77 & 0.71 & 0.77 & 0.79 & 0.86 & 0.95 & 1 & & \\
\hline 24 & 0.54 & 0.53 & \begin{tabular}{l|l} 
\\
\end{tabular} & 0.50 & \begin{tabular}{l|l}
0.53 \\
\end{tabular} & 0.71 & 0.70 & 0.69 & 0.70 & 0.66 & 0.61 & 0.71 & 0.70 & 0.65 & 0.70 & 0.63 & 0.70 & 0.63 & 0.73 & 0.75 & 0.78 & 0.85 & 0.90 & 1 & \\
\hline 25 & 0.54 & 0.57 & \begin{tabular}{l|l}
0.57 \\
\end{tabular} & 0.59 & $\begin{array}{ll}0.62 \\
\end{array}$ & 0.76 & 0.75 & 0.71 & 0.73 & 0.69 & 0.64 & \begin{tabular}{l|l}
0.72 & \\
\end{tabular} & \begin{tabular}{l|l}
0.76 \\
\end{tabular} & 0.69 & 0.75 & 0.63 & 0.76 & 0.68 & 0.77 & 0.74 & 0.81 & 0.90 & 0.93 & 0.93 & \\
\hline
\end{tabular}

Table 8: Genetic similarity matrix of five A. graecorum populations (bulked DNA samples) as computed according to Dice's coefficient from ISSR data. Alhagi populations are numbered (1-5); 1. El-Dakhla Oasis, 2. Ain Shams University, 3. Wadi El-Rayan, 4. Qarun Lake and 5. Siwa Osis.

\begin{tabular}{llllll}
\hline & $\mathbf{1}$ & $\mathbf{2}$ & $\mathbf{3}$ & $\mathbf{4}$ & $\mathbf{5}$ \\
\hline $\mathbf{1}$ & 1 & & & & \\
$\mathbf{2}$ & 0.519 & 1 & & & \\
$\mathbf{3}$ & 0.595 & 0.689 & 1 & & \\
$\mathbf{4}$ & 0.542 & 0.716 & 0.684 & 1 & 1 \\
$\mathbf{5}$ & 0.547 & 0.778 & 0.645 & 0.853 & \\
\hline
\end{tabular}




\section{Ghada M. Abd El- hak et. al}

University populations. The result of the similarity index values (0.99) as mostly similar to Pérez de la Torre et al (2012) who reported simple matching coefficient of similarity varied from 0.8875 to 0.6659 in Calibrachoa caesia, indicating high levels of genetic similarity among the genotypes studied. Also, this is in agreement with the findings of TurhanSerttaş and Özcan (2018) they examined the similarity matrix with Jaccard's coefficient (0.933) in Pistacia lentiscus varieties. In addition, Okon et al. (2013), who amplified chamomile germplasm using ISSR primers and calculate the mean genetic similarity at 0.653 .

\section{Cluster analysis as revealed by ISSR markers and principal coordinates analysis}

Based on the polymorphic ISSR fragments generated by 8 primers for 25 individuals, a dendrogram was constructed by cluster analysis of ISSR-based genetic distance using UPGMA cluster analysis (Figure 4A). The obtained dendrogram was divided into two main clusters the first cluster comprises El-Dakhla population (15 ), while the second cluster is divided into two sub-clusters. The first includes Ain Shams University population (6-10) and the second sub-cluster could be further divided into two groups. Populations coming from Wadi El-Rayan (11-15) and Qarun Lake (16-20) were classified in group I and Siwa Oasis population (21-25) were clustered in group II. On the dendrogram, all the individuals collected from the same region were grouped together. The resulting ISSR dendrogram from bulked DNA Alhagi populations, are differentiated into two clusters, the first cluster represented by ElDakhla Oasis population only. The second cluster differentiated into two sub-clusters, first sub-cluster contain Wadi El-Rayan population while other remained populations represented the second subcluster, which further differentiated into two groups; the first contain Ain Shams University population while the second include both Qarun Lake and Siwa Oasis populations together (Figure 4B).

The relationship observed in the principle coordinate analysis (PCoA) was in agreement with the UPGMA analysis of 25 individuals; where group A contains ElDakhla Oasis population, group B comprised Ain Shams University population, group $C$ having all Siwa Oasis individuals and group D comprised Wadi El-Rayan and Qarun Lake populations (Figure 5a). Whereas the PCoA resulted from ISSR marker classified the five $A$. graecorum populations into three groups (Figure 5b), group A comprises El-Dakhla Oasis population, and group $\mathrm{B}$ contains Wadi El-Rayan population and group $\mathrm{C}$ with the remaining three populations (Ain Shams University, Qarun Lake and Siwa Oasis populations). The populations in this study were clustered according to the degree of similarity of their habitats and had nothing to do with their geographical location, the populations with similar habitats firstly clustered together to form a specific clade as Zou et al. (2011) who constructed a dendrogram using the UPMGA method. Geographic difference caused great differentiation within populations. On the basis of genetic distances, we constructed a dendrogram of genetic similarities of the studied genotypes with the use of the method UPGMA (Figure 4). From the dendrogram, we see that, all the individuals collected from the same region were grouped together. The pattern of genetic subdivision can be clearly demonstrated in the UPGMA cluster analysis, in which similar to the populations of Mallotus oblongifolius which divided into two groups according to their habitat type (Yan et al., 2019). The results of PCoA analysis also support this habitatspecific genetic clustering model.

Also, Sica et al. (2005) studied a genetic diversity in Italian Asparagus acutifolius using twenty-three ISSR primers, the distance UPGMA tree grouped together the genotypes strictly according to their geographical origin, showing that each 
Genetic variation within and among the wild populations

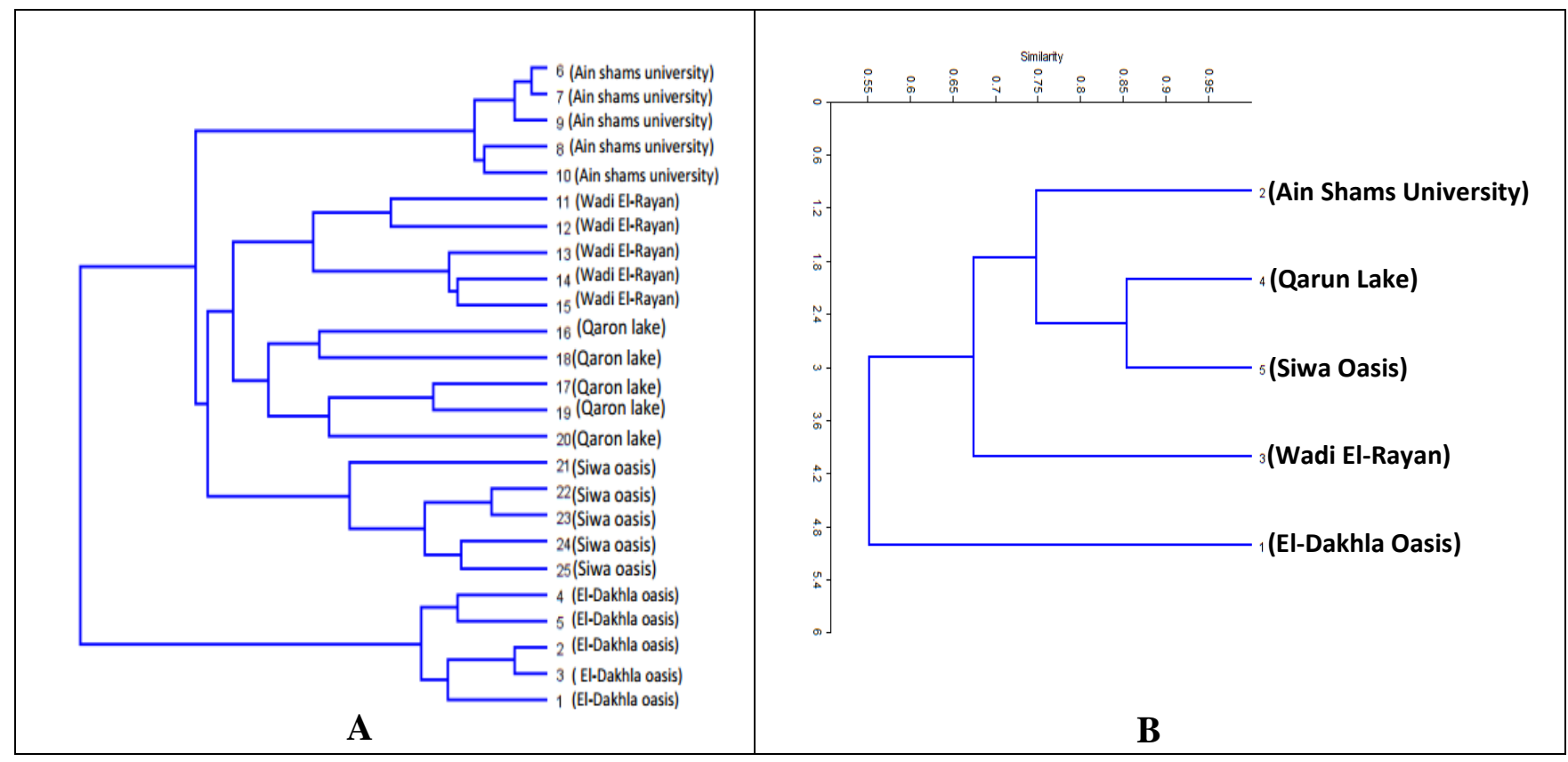

Figure 4: Dendrograms for A) 25 A. graecorum genotypes (1-25) B) five Alhagi graecorum populations (bulked DNA samples) constructed from the ISSR data using Unweighed Pair-group Arithmetic Average (UPGMA) and similarity matrix computed according to Dice's coefficient. Populations: 1. El-Dakhla Oasis; 2. Ain Shams University; 3. Wadi El-Rayan; 4. Qarun Lake; 5. Siwa Oasis.

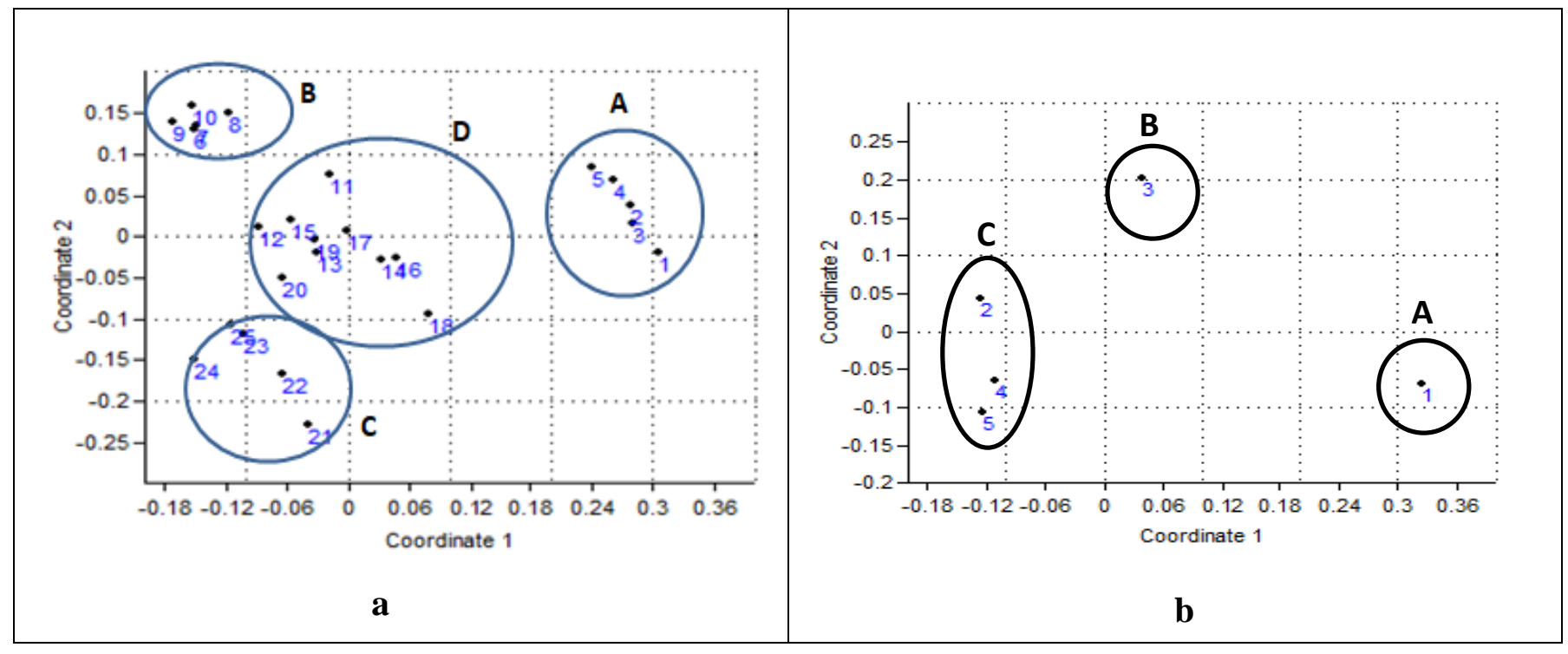

Figure 5: Scatter plot of principal coordinate analysis (PCoA) for a) 25 Alhagi individuals b) 5 Alhagi populations (bulked DNA samples) based on ISSR marker data: 1. El-Dakhla Oasis; 2. Ain Shams University; 3. Wadi ElRayan; 4. Qarun Lake; 5. Siwa Oasis. 
sample is genetically structured and can be considered as distinct population. There are many researchers determined the level of genetic diversity and relatedness in different plants as Hagenia abyssinica (Feyissa et al., 2007), strawberry (Debnath et al., 2008), Calibrachoa caesia (Pérez de la Torre et al., 2012) and Pistacia lentiscus (Turhan-Serttaş and Özcan, 2018) using UPGMA cluster and/or PCoA analysis.

\section{CONCLUSION}

To author knowledge, this is the first molecular marker reported based on genetic diversity study of $A$. graecorum. In the present study, the large number of polymorphic bands suggested that ISSR primers have been used successfully to study and analyse the genetic relationships within and among Alhagi populations. The molecular variations assessing of $A$. graecorum was 63\% among populations while variation within populations accounted for the remaining 37\%. The highest similarity was recorded between genotypes 6 and 7 (both individuals from Ain Shams University population) within the 25 Alhagi genotypes, while among the different five populations was between Qarun Lake and Siwa Oasis populations. The results obtained in this work indicated that ISSR are useful markers in genetic diversity assessment.

\section{REFERENCES}

Agarwal, T., Gupta, A. K., Patel, A. K. and Shekhawat, N. S. (2015) Micropropagation and validation of genetic homogeneity of Alhagi maurorum using SCoT, ISSR and RAPD markers. Plant Cell, Tissue and Organ Culture (PCTOC), 120(1): 313-323.

Akagi, H., Yokozeki, Y., Inagaki, A. and Fujimura, T. (1996) Microsatellite DNA markers for rice chromosomes. Theoretical and Applied Genetics, 93(7): 1071-1077.

Alansi, S., Tarroum, M., Al-Qurainy, F., Khan, S. and Nadeem, M. (2016) Use of ISSR markers to assess the genetic diversity in wild medicinal Ziziphus spina-christi
(L.) Willd. collected from different regions of Saudi Arabia. Biotechnology \& Biotechnological Equipment, 30(5): 942947.

Aldoori, S.A., Abido, A.I., Gaber M.K., Elmahroq, E.M., El-Torky, M.G. and Hegazy, A.E. (2019) Differentiation between in vivo and in vitro Pongamia pinnata based on Inter Simple Sequence Repeat and Random amplified polymorphic DNA markers. Middle East Journal of Applied Sciences 09:110-116.

Ali, S. I. (1977) Significance of flora with special reference to Pakistan. Pakistan Jourmal of Botany, 40(3): 967-971.

Almeida-Pereira, C. S., Muniz, A. V. C. D. S., Alves, R. P., Feitosa-Alcantara, R. B., Arrigoni-Blank, M. D. F., Carvalho, S. V. Á. and Blank, A. F. (2017) Genetic diversity of native populations of Croton tetradenius Baill. using ISSR markers. Genetics and Molecular Research, 16(2) http://dx.doi.org/10.4238/gmr16029602.

Ansari, S.A., Narayanan, C., Wali, S.A., Kumar, R., Shukla, N. and Rahangdale, S.K. (2012) ISSR markers for analysis of molecular diversity and genetic structure of Indian teak (Tectona grandis L.f.) populations. Annals of Forest Research, 55(1): 11-23.

Araújo, F.S., Pacheco, M.V., Vieira, F.A. and Ferrari, C.S. (2016) ISSR molecular markers for the study of the genetic diversity of Mimosa caesalpiniaefolia Benth. Idesia, 34(3): 47-52.

Arolu, I. W., Rafii, M. Y., Hanafi, M. M., Mahmud, T. M. M. and Latif, M. A. (2012) Molecular characterization of Jatropha curcas germplasm using inter simple sequence repeat (ISSR) markers in Peninsular Malaysia. Australian Journal of Crop Science, 6(12): 1666- 1673.

Badshah, L. and Hussain, F. (2011) People preferences and use of local medicinal flora in District Tank, Pakistan. Journal of Medicinal Plants Research, 5(1): 22-29.

Bhagyawant, S.S. and Srivastava, N. (2008) Genetic fingerprinting of chickpea (Cicer arietinum L.) germplasm using ISSR 


\section{Genetic variation within and among the wild populations}

markers and their relationships. African Journal of Biotechnology, 7 (24): 4428 4431.

Blair, M.W., Panaud, O. and McCouch, S.R. (1999) Inter-simple sequence repeat (ISSR) amplification for analysis of microsatellite motif frequency and fingerprinting in rice (Oryza sativa L.). Theoretical and Applied Genetics, 98:780792.

Boulos, L. (1966) Flora of the Nile region in Egyptian Nubia. Feddes Repertorium, 73(3): 184-215.

Boulos, L. (1999). Flora of Egypt, vol. 1. Cairo: Al Hadara Publishing, 417.

Cabral, P.D.S., Souza, L. C., Costa, G. F., Silva, F. H. L., and Soares, T.C.B. (2018) Investigation of the genetic diversity of common bean (Phaseolus vulgaris) cultivars. Genetics and Molecular Research, 17(4):1-11.

Costa, J. C., Fracetto, G. G. M., Fracetto, F. J. C., Souza, T. C., Santos, M. V. F. and Junior, M. L.(2019) Genetic diversity in natural populations of Stylosanthes scabra Fabaceae using ISSR markers. Genetics and Molecular Research, 17(1) http://dx.doi.org/10.4238/gmr18219.

Debnath, S. C., Khanizadeh, S., Jamieson, A. R. and Kempler, C. (2008) Inter simple sequence repeat (ISSR) markers to assess genetic diversity and relatedness within strawberry genotypes. Canadian journal of plant science, 88(2): 313-322.

Dice, L.R. (1945) Measures of the amount of ecologic association between species. Ecology, 26: 297-302.

Doyle, J.J. and Doyle, J.L. (1990) Isolation of plant DNA from fresh tissue. Focus, 12: 13-15.

Ducar, E., Rewers, M., Jedrzejczyk, I., Martonfi, P. and Sliwinska, E. (2018) Comparison of the genome size, endoreduplication, and ISSR marker polymorphism in eight Lotus (Fabaceae) species. Turkish Journal of Botany, 42(1): 1-14.

Etminan, A., Pour-Aboughadareh, A., Mohammadi, R., Ahmadi-Rad, A.,
Noori, A., Mahdavian, Z. and Moradi, Z. (2016) Applicability of start codon targeted (SCoT) and inter-simple sequence repeat (ISSR) markers for genetic diversity analysis in durum wheat genotypes. Biotechnology \& Biotechnological Equipment, 30(6): 1075-1081.

Feyissa, T., Nybom, H., Bartish, I. V. and Welander, M. (2007) Analysis of genetic diversity in the endangered tropical tree species Hagenia abyssinica using ISSR markers. Genetic Resources and Crop Evolution, 54(5): 947-958.

Geleta, M. and Bryngelsson, T. (2009) Inter simple sequence repeat (ISSR) based analysis of genetic diversity of Lobelia rhynchopetalum (Campanulaceae). Hereditas, 146(3): 122-130.

Gelotar, M. J., Dharajiya, D. T., Solanki, S. D., Prajapati, N. N. and Tiwari, K. K. (2019) Genetic diversity analysis and molecular characterization of grain amaranth genotypes using inter simple sequence repeat (ISSR) markers. Bulletin of the National Research Centre, 43(1): 103 (https://doi.org/10.1186/s42269-019-01462).

Gonzalez, A., Coulson, A. and Brettell, R. (2002) Development of DNA markers (ISSRs) in mango. Acta Horticulture, 575:139-143.

Gower, J.C. (2015) Principle coordinates analysis. Wiley Stats Ref: Statistics Reference Online.

Hammer, R., Harper, D. and Ryan, P. (2001) PAST: Paleontological statistics software package for education and data analysis. In. Palaeontologia Electronica.

Hassanein, A. M. and Mazen, A. M. A. (2001) Adventitious bud formation in Alhagi graecorum. Plant Cell, Tissue and organ culture, 65(1): 31-35.

Ismail, N. A., Rafii, M. Y., Mahmud, T. M. M., Hanafi, M. M. and Miah, G. (2019) Genetic Diversity of Torch Ginger (Etlingera elatior) Germplasm Revealed by ISSR and SSR Markers. BioMed research international, $\quad 4$ : 1-14 (https://doi.org/10.1155/2019/5904804). 
Joshi, S. P., Gupta, V. S., Agarwal, R. K., Ranjekar, P. K. and Brar, D. S. (2000) Genetic diversity and phylogenetic relationship as revealed by inter simple sequence repeat (ISSR) polymorphism in the genus Oryza. Theoretical and Applied Genetics, 100(8): 1311-1320.

Karaca, M. and Izbirak, A. (2008) Comparative analysis of genetic diversity in Turkish durum wheat cultivars using RAPD and ISSR markers. Journal of food, agriculture \& environment, 6: 219-225.

Kawase, K. and Kanno, I. (1983) Soils of China: their use and improvement, nature of fertility and soil properties, and genesis, classification and distribution. Hakuyusha, Tokyo (in Japanese), 854-888.

Khazaei, H., Caron, C. T., Fedoruk, M., Diapari, M., Vandenberg, A., Coyne, C. J. and Bett, K. E. (2016) Genetic diversity of cultivated lentil (Lens culinaris Medik.) and its relation to the World's agroecological zones. Frontiers in plant science, 7: 1093.

Kosman, E. and Leonard, K. J. (2005) Similarity coefficients for molecular markers in studies of genetic relationships between individuals for haploid, diploid, and polyploid species. Molecular ecology, 14(2): 415-424.

Liu, Q., Song, Y., Liu, L., Zhang, M., Sun, J., Zhang, S. and Wu, J. (2015) Genetic diversity and population structure of pear (Pyrus spp.) collections revealed by a set of core genome-wide SSR markers. Tree genetics \& genomes, 11(6): 128 (doi: 10.1007/s11295-015-0953-z).

Ma, X., Zhang, X. Q., Zhou, Y. H., Bai, S. Q. and Liu, W. (2008) Assessing genetic diversity of Elymus sibiricus (Poaceae: Triticeae) populations from Qinghai-Tibet Plateau by ISSR markers. Biochemical Systematics and Ecology, 36(7): 514-522.

Meikle, R. D. (1977). Flora of Cyprus. Flora of Cyprus. Volume One.

Meyer, W., Lieckfeldt, E., Kuhls, K., Freedman, E. Z., Börner, T. and Mitchell, T. G. (1993) DNA-and PCRfingerprinting in fungi. In DNA fingerprinting: State of the Science (pp. 311-320).

Monfared, M. A., Samsampour, D., Sharifi-Sirchi, G. R. and Sadeghi, F. (2018) Assessment of genetic diversity in Salvadora persica L. based on inter simple sequence repeat (ISSR) genetic marker. Journal of Genetic Engineering and Biotechnology, 16(2): 661-667.

Moradkhani, H., Mehrabi, A. A., Etminan, A. and Pour-Aboughadareh, A. (2015) Molecular diversity and phylogeny of Triticum-Aegilops species possessing D genome revealed by SSR and ISSR markers. Plant Breeding and Seed Science, 71(1): 81-95.

Mosula, M. Z., Konvalyuk, I. I., Mel'nyk, V. M., Drobyk, N. M., Tsaryk, Y. V., Nesteruk, Y. Y. and Kunakh, V. A. (2014) Genetic polymorphism of Gentiana lutea L.(Gentianaceae) populations from the Chornohora Ridge of the Ukrainian Carpathians. Cytology and genetics, 48(6): 371-377.

Nagaoka, T. and Ogihara, Y. (1997). Applicability of inter-simple sequence repeat polymorphisms in wheat for use as DNA markers in comparison to RFLP and RAPD markers. Theoretical and applied genetics, 94(5): 597-602.

Okon, S., Surmacz-Magdziak, A. and Paczos-GrzĊda, E. (2013) Genetic diversity among cultivated and wild chamomile germplasm based on ISSR analysis. Acta Scientiarum Polonorum, Hortorum Cultus, 12(2): 43-50.

Olatunji, T. L. and Afolayan, A. J. (2019)

Evaluation of genetic relationship among varieties of Capsicum annuum $\mathrm{L}$. and Capsicum frutescens L. in West Africa using ISSR markers. Heliyon, 5(5): e01700. Pavoine, S., Dufour, A. B. and Chessel, D. (2004) From dissimilarities among species to dissimilarities among communities: a double principal coordinate analysis. Journal of theoretical biology, 228(4): 523537.

Pérez de la Torre, M., García, M., Heinz, R. and Escandón, A. (2012) Analysis of genetic variability by ISSR markers in 
Calibrachoa caesia. Electronic Journal of Biotechnology, 15(5): 8 (DOI: 10.2225/vol15-issue5-fulltext-8).

Powell, W., Morgante, M., Andre, C., Hanafey, M., Vogel, J., Tingey, S. and Rafalski, A. (1996) The comparison of RFLP, RAPD, AFLP and SSR (microsatellite) markers for germplasm analysis. Molecular breeding, 2(3): 225238.

Rakoczy-Trojanowska, M. O. N. I. K. A. and Bolibok, H. (2004) Characteristics and a comparison of three classes of microsatellite-based markers and their application in plants. Cellular and Molecular Biology Letters., 9(2): 221-238.

Ranade, S.A. and Farooqui, N. (2002) Assessment of Profile Variations Amongst Provenances of Neem Using SinglePrimer-Amplification Reaction (SPAR) Techniques. Molecular Biology Today, 3(1): 1-10.

Ranjbarfard, A., Saleh, G., Abdullah, N.A.P. and Kashiani, P. (2014) Genetic diversity of lemba (Curculigo latifolia) populations in Peninsular Malaysia using ISSR molecular markers. Australian Journal of Crop Science, 8: 9-17.

Rao, V. R. and Hodgkin, T. (2002) Genetic diversity and conservation and utilization of plant genetic resources. Plant cell, tissue and organ culture, 68(1): 1-19.

Ratnaparkhe, M. B., Tekeoglu, M. and Muehlbauer, F. J. (1998) Inter-simplesequence-repeat (ISSR) polymorphisms are useful for finding markers associated with disease resistance gene clusters. Theoretical and Applied Genetics, 97(4): 515-519.

Rawat, S., Arunkumar, A.N., Annapurna, D. Karaba, N.N. and Joshi, G. (2018) Genetic diversity of Melia dubia using ISSR markers for natural populations and Plantations. International Journal of Genetics, 10(9): 490-494.

Reddy, M. P., Sarla, N. and Siddiq, E. A. (2002) Inter simple sequence repeat (ISSR) polymorphism and its application in plant breeding. Euphytica, 128(1): 9-17.
Sahoo, D. P., Aparajita, S. and Rout, G. R. (2010) Inter and intra-population variability of Pongamia pinnata: a bioenergy legume tree. Plant Systematics and Evolution, 285(1-2): 121-125.

Sankar, A.A. and Moore, G.A. (2001) Evaluation of inter-simple sequence repeat analysis for mapping in Citrus and extension of genetic linkage map. Theoretical and Applied Genetics, 102: 206-214.

Shilpa, J. B. and Krishnan, S. (2016) Molecular genetic diversity of landraces, cultivars and wild relatives of rice of Goa. Current Science, 111(10): 1675 (doi: 10.18520/cs/v111/i10/1675-1679).

Sica, M., Gamba, G., Montieri, S., Gaudio, L. and Aceto, S. (2005) ISSR markers show differentiation among Italian populations of Asparagus acutifolius L. BMC genetics, 6(1): 17 (doi: 10.1186/14712156-6-17).

Sneath, P. and Sokal, R. (1973) Numerical Taxonomy. San Francisco, California.

Sokal, R.R. and Michener, C.D. (1958) A statistical method for evaluating systematic relationship. The University of Kansas science bulletin, 38: 1409 -1438.

Tackholm, V. (1974) Students Flora of Egypt, 2nd ed. Cairo, Egypt, The Cooperative Printing Company, p. 657.

Tanya, P., Taeprayoon, P., Hadkam, Y. and Srinives, P. (2011) Genetic diversity among Jatropha and Jatropha-related species based on ISSR markers. Plant Molecular Biology Reporter, 29(1): 252264.

Tapeh, R. N. G., Bernousi, I., Moghadam, A. F. and Abdollahi, B. (2018) Genetic Diversity and Structure of Iranian Teucrium (Teucrium polium L.) Populations Assessed by ISSR Markers. Journal of Agricultural Science and Technology, 20(2): 333-345.

Thimmappaiah, Santhosh, W.G., Shobha, D. and Melwyn, G.S. (2009) Assessment of genetic diversity in cashew germplasm using RAPD and ISSR markers. Scientia Horticulturae, 120: 411-417. 


\section{Ghada M. Abd El- hak et. al}

Tikunov, Y. M., Khrustaleva, L. I. and Karlov, G. I. (2003) Application of ISSR markers in the genus Lycopersicon. Euphytica, 131(1): 71-81.

Tsumura, Y., Ohba, K. and Strauss, S.H. (1996) Diversity and inheritance of intersimple sequence repeat polymorphisms in Douglasfir (Pseudotsuga menziesii) and sugi (Cryptomeria japonica). Theoretical and Applied Genetics, 92: 40-45.

Turhan-serttş, P. and özcan, T. (2018) Intraspecific Variations Studied by ISSR and IRAP Markers in Mastic Tree (Pistacia lentiscus L.) from Turkey. Trakya University Journal of Natural Sciences, 19(2): 147-157.

Verma, S. and Rana, T. S. (2011) Genetic diversity within and among the wild populations of Murraya koenigii ( L .) Spreng as revealed by ISSR analysis. Biochemical Systematics and Ecology, 39(2): 139-144.

Wang, G., Mahalingan, R. and Knap, H.T. (1998) (C-A) and (GA) anchored simple sequence repeats (ASSRs) generated polymorphism in soybean, Glycine max (L.) Merr. Theoretical and Applied Genetics, 96: 1086-1096.
Weising, K., Atkinson, R. G. and Gardner, R. C. (1995) Genomic fingerprinting by microsatellite-primed PCR: a critical evaluation. Genome Research, 4(5): 249-255.

Yan, W., Li, J., Zheng, D., Friedman, C. and Wang, H. (2019) Analysis of genetic population structure and diversity in Mallotus oblongifolius using ISSR and SRAP markers. Peer Journal, 7: e7173.

Zhang, L. J. and Dai, S. L. (2010) Genetic variation within and among populations of Orychophragmus violaceus (Cruciferae) in China as detected by ISSR analysis. Genetic resources and crop evolution, 57(1): 55-64.

Zietkiewicz, E., Rafalski, A. and Labuda, D. (1994) Genome fingerprinting by simple sequence repeat (SSR) - anchored polymerase chain reaction amplification. Genomics, 20: 176-183.

Zou, Z., Gui, Z., Yu, L., Chen, F. and Xia, B. (2011) Genetic diversity within and among populations of Acarus siro L. revealed by inter simple sequence repeats (ISSR). Procedia Environmental Sciences, 8: 707-714. 